Review

\title{
Contribution of large-scale forest inventories to biodiversity assessment and monitoring
}

\author{
Piermaria Corona ${ }^{\mathrm{a}, 1}$, Gherardo Chirici ${ }^{\mathrm{b}, 2}$, Ronald E. McRoberts ${ }^{\mathrm{c}, 3}$, Susanne Winter ${ }^{\mathrm{d}, 4}$, Anna Barbati ${ }^{\mathrm{a}, *}$ \\ ${ }^{a}$ Dipartimento per la Innovazione nei sistemi Biologici, Agroalimentari e Forestali, Università della Tuscia, via San Camillo de Lellis, 01100 Viterbo, Italy \\ ${ }^{\mathrm{b}}$ Dipartimento di Scienze Tecnologie Ambientali Forestali, Università del Molise, Contrada F.te Lappone, 86090 Pesche, Isernia, Italy \\ ${ }^{\mathrm{c}}$ Northern Research Station, U.S. Forest Service, 1992 Folwell Avenue, St. Paul, MN 55108, USA \\ ${ }^{\mathrm{d}}$ Technische Universität München, Department of Ecology and Ecosystem-Management, Geobotany, Hans-Carl-von-Carlowitz-Platz 2, D-85354 Freising, Germany
}

\section{A R T I C L E I N F O}

\section{Article history:}

Received 25 May 2011

Received in revised form 19 August 2011

Accepted 28 August 2011

\section{Keywords:}

Forest biodiversity indicators

Probabilistic sampling

Forest types

Landscape metrics

\begin{abstract}
A B S T R A C T
Statistically-designed inventories and biodiversity monitoring programs are gaining relevance for biological conservation and natural resources management. Mandated periodic surveys provide unique opportunities to identify and satisfy natural resources management information needs. However, this is not an end in itself but rather is the beginning of a process that should lead to sound decision-making in biodiversity conservation. Forest inventories are currently evolving towards multipurpose resource surveys and are broadening their scope in several directions: (i) expansion of the target population to include non-traditional attributes such as trees outside the forest and urban forests; (ii) forest carbon pools and carbon sequestration estimation; (iii) assessment of forest health; and (iv) inclusion of additional variables such as biodiversity attributes that are not directly related to timber assessment and wood harvesting.

There is an on-going debate regarding the role of forest inventories in biodiversity assessment and monitoring. This paper presents a review on the topic that aims at providing updated knowledge on the current contribution of forest inventories to the assessment and monitoring of forest biodiversity conditions on a large scale. Specific objectives are fourfold: (i) to highlight the types of forest biodiversity indicators that can be estimated from data collected in the framework of standard forest inventories and the implications of different sampling methods on the estimation of the indicators; (ii) to outline current possibilities for harmonized estimation of biodiversity indicators in Europe from National Forest Inventory data; (iii) to show the added value for forest biodiversity monitoring of framing biodiversity indicators into ecologically meaningful forest type units; and (iv) to examine the potential of forest inventory sample data for estimating landscape biodiversity metrics.
\end{abstract}

(c) 2011 Elsevier B.V. All rights reserved.

\section{Contents}

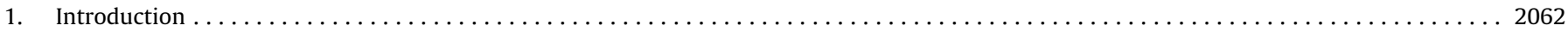

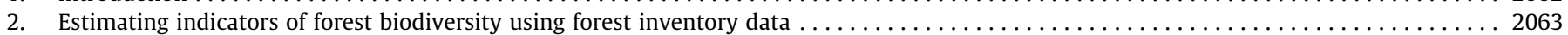

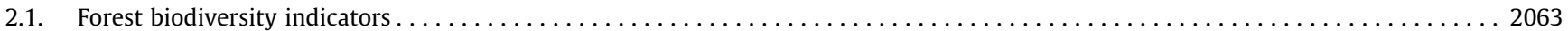

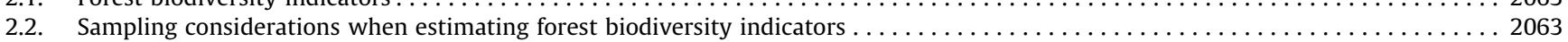

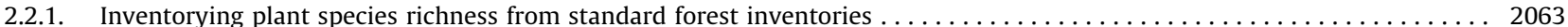

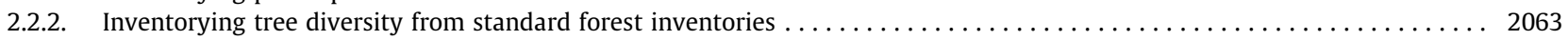

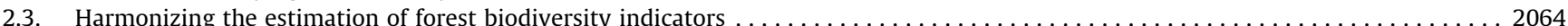

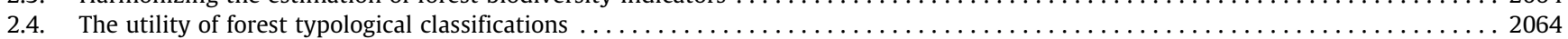

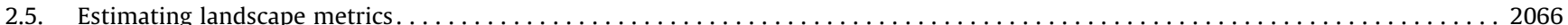
\footnotetext{
barbati.sisfor@unitus.it (A. Barbati).

1 Tel.: +390761 357425; fax: +390761357389.

2 Tel./fax: +390874404138 .

3 Tel.: +1 651649 5174; fax: +1 6516495140 .

4 Tel.: +49 8161714772 ; fax: +498161 714738
}

* Corresponding author. Tel.: +39 0761 357406; fax: +39 0761357389.

E-mail addresses: piermaria.corona@unitus.it (P. Corona), gherardo.chirici@uni mol.it (G. Chirici), rmcroberts@fs.fed.us (R.E. McRoberts), winter@wzw.tum.de (S. Winter), 